\title{
Development of finger millet based probiotic beverage using Lactobacillus casei431 ${ }^{\oplus}$
}

\author{
M.M.F. Fasreen ${ }^{1}$, O.D.A.N. Perera ${ }^{1}$ and H.L.D. Weerahewa ${ }^{2^{*}}$ \\ ${ }^{1}$ Department of Food Science and Technology, Wayamba University of Sri Lanka \\ ${ }^{2}$ Department of Botany, Faculty of Natural Sciences, The Open University of \\ Sri Lanka
}

\section{Abstract}

Finger millet (Eleusine coracana) based probiotic beverage was formulated which comprises of health benefits from both finger millet and probiotic. Cooked finger millet was inoculated with Lactobacillus casei431 and incubated at $37^{\circ} \mathrm{C}$ for $2 \mathrm{~h}, 4 \mathrm{~h}$, and $6 \mathrm{~h}$. The beverage was formulated with the addition of sucrose, fresh cow milk, and cocoa powder, and stored under refrigerated $\left(5 \pm 1^{\circ} \mathrm{C}\right)$ conditions. Sensory evaluation was conducted to select the best fermented time and the highest acceptability was achieved by the sample fermented for $4 \mathrm{~h}$. Changes in physicochemical characteristics $(\mathrm{pH}$, titratable acidity, brix, and reducing/non-reducing sugars) and viable cell counts during refrigeration were monitored.

pH was decreased from 7.10 (SD 0.01) to 5.05 (SD 0.00) and titratable acidity was increased significantly $(p<0.05)$ due to lactic acid production by probiotic. Reducing and non-reducing sugars were decreased significantly $(p<0.05)$ because of usage by probiotics. This study concludes that finger millet based probiotic beverage can be developed with L.casei431 $1^{\circ}$ and it could be kept in refrigerated $\left(5 \pm 1^{\circ} \mathrm{C}\right)$ storage up to 5 weeks.

Keywords: Finger millet; Functional foods; Probiotics; Health benefits

\footnotetext{
* Corresponding Author: H.L.D. Weerahewa email: weerahewa@gmail.com http://orcid.org/0000-0002-2132-9951 (Received 31 March 2017; Revised 13 July 2017; Accepted 20 July 2017) (c) OUSL
} 


\section{Introduction}

Probiotics are defined as live microbial that beneficially affect the hosts by improving its intestinal microbial balance when administrated in adequate amounts (Fuller, 1989). Many researches prove that addition of probiotics to foods leads to several health benefits including the reduction of the level of serum cholesterol, the improvement of gastro intestinal function, the enhancement of the immune system, the inhibition of diarrhoea in young children and the lowering of the risk of colon cancer (Berner \& Donnel, 1998). Most of the probiotics are lactic acid bacteria and traditionally dairy products have been the vehicles for the delivery of probiotics. But recently, consumer demand has converted to non-diary based probiotic products such as fruits and vegetables and cereal based products because of cholesterol level, lactose intolerance which is related to diary product consumption and the increased popularity of vegetarianism. The recent investigations carried out by Gamage, Mihirani, Perera and Weerahewa (2016) and Alwis, Perera, and Weerahewa (2016) indicated that incorporation of Lactobacillus casei 431 in to carrot juice and beet root juice have proven to be use as an effective synbiotic beverage.

Finger millet (Eluesine coracana), is nutritionally an excellent source of minerals, especially Ca, K, P and Mg (Sripriya, Chandrasekharan, Murthy \& Chandra,1996) that contributes to a large part of the recommended dietary allowance value. By considering richness of dietary fibres and other carbohydrates in finger millets, probabilities can be made for finger millet based probiotic product developments. However, considerable researches have not been devoted to check viability of probiotics in cereal based products including finger millet. Recently, there has been a growing interest in probiotic cereals, fruits and vegetable products.

Accordingly, the present study aimed to determine the survivability of probiotic bacteria L.casei431 in finger millet based beverage throughout refrigerated storage.

\section{Methodology}

\section{Preparation of finger millet beverage}

Finger millet grains were thoroughly washed and the impurities which appeared on the top of the water was discarded with the water. The grains were roasted for 3 minutes. The roasted finger millet was ground and sieved. Then $25 \mathrm{~g}$ of flour was cooked with $500 \mathrm{~mL}$ of water in a sterilized container. When the solution was boiled at $78^{\circ} \mathrm{C}$, it was retained for a further 10 minutes. When the solution was cooled to 
$40^{\circ} \mathrm{C}, 0.031 \mathrm{gL}^{-1}$ of Lactobacillus casei $431^{\circ}$ commercial frozen probiotic culture $(\mathrm{CH}-$ HANSON - Denmark) was added and incubated at $37^{\circ} \mathrm{C}$ for 2, 4 and 6 hours respectively. Subsequently, $150 \mathrm{ml}$ of milk was pasteurized $\left(78^{\circ} \mathrm{C} 1 \mathrm{~min}\right.$ ) and $46 \mathrm{~g} / \mathrm{L}$ of sugar, $7.9 \mathrm{~g} / \mathrm{L}$ of cocoa powder were added to the milk and mixed well. This mixture was added to the fermented finger millet solution which was kept in the incubator previously and mixed well, filled to sterilized glass bottles and sealed.

Sensory evaluation was conducted to select the best fermentation time. Moreover, color, odor, taste, acidity, viscosity and overall acceptability were evaluated using 30 untrained panelists. Finally, the highest scored beverage was selected for the proximate analysis and refrigerated $\left(5^{\circ} \mathrm{C} \pm 1\right)$. Physico-chemical $(\mathrm{pH}$, titratable acidity, brix, total reducing sugars, total sugar, sucrose level, crude fiber content) and microbiological parameters(total viable counts of L.casei $\left(31^{\circ}\right.$ and yeast and mold count) were evaluated once a week.

\section{Proximate composition analysis}

Protein content (Kjeldhal method), crude fat content (Soxhlet method), crude fiber content, carbohydrate content and ash content were analyzed using A.O.A.C. (2000) methods.

Physico-chemical analysis of the beverage

The $\mathrm{pH}$ ( $\mathrm{pH}$ meter (OHAUS- USA), acidity based on lactic acids (acid- base titration method (Sharma, 2006), total soluble solids expressed as sucrose amount refractometer (ATAGO- Japan) (Sharma, 2006) and presence of added sucrose were detected using A.O.A.C. (2000) methods.

Microbiological analysis of the beverage

Viable Lactobacillus casei $431^{\circ}$ bacteria was enumerated by spread plate count technique on MRS (De Man, Rogosa, Sharpe agar) (HiMedia - India). Plates were incubated as inverted position at $37{ }^{\circ} \mathrm{C}$ in an anaerobic condition using an anearogen sachet for $24 \mathrm{~h}$. Spread plate count technique on Potato dextrose agar (HiMedia India) was used to measure yeast and mold count (Collins, Lyne\&Grange, 2004).Catalase test (Nelson \&George, 1995), Gram staining test (Collins et al., 2004) and endospore staining test (Gerhardt, Murray, Wood \& Krieg, 1994) were used as confirmation tests for L.casei. 
Shelf life Determination

Sensory evaluations on color, odor, acidity flavor and overall acceptability were conducted once in two weeks. $\mathrm{pH}$, titratable acidity, viable $L$. casei and yeast and mold counts were examined to evaluate the shelf life of probiotic finger millet beverage.

\section{Statistical analysis}

Non-parametric tests were performed to determine the statistical difference of the sensory data, and where appropriate, T-tests were performed for comparison of two means. Significant differences between the results were assessed by analysis of variance (ANOVA) with the help of SPSS software. The results of proximate analysis were the average of triplicate experiments and were expressed as mean \pm SD. Differences at $0<0.05$ was considered statistically significant for all analyses.

\section{Results}

\section{Sensory evaluation for best fermentation time selection}

Table 1 \& Table 2: Kruskal Wallis test for five point hedonic scale tests for the treatments

\begin{tabular}{llr}
\hline \multicolumn{3}{c}{ Ranks } \\
treatment & $\mathrm{N}$ & Mean Rank \\
scale 2 & 180 & 292.90 \\
4 & 180 & 241.99 \\
6 & 180 & 276.61 \\
Total & 540 & \\
\hline
\end{tabular}

\begin{tabular}{lr}
\multicolumn{2}{c}{ Test Statistics $^{\mathrm{a}, \mathrm{b}}$} \\
\hline \multicolumn{2}{c}{ scale } \\
\hline Chi-Square & 11.982 \\
df & .003 \\
Significant (P) value & \\
\hline a. Kruskal Wallis Test & \\
b. Grouping Variable: treatment (hours)
\end{tabular}

According to the results of Kruskal-Wallis test, overall the lowest mean score was recorded by the $4 \mathrm{~h}$ fermented sample while the highest mean score was recorded by $2 \mathrm{~h}$ fermented sample. According to the ranks given in the scale, the lowest mean value of ranks should be obtained by the best sample and it was shown by $4 \mathrm{~h}$ fermented sample which was selected as the best time of fermentation. 


\section{Proximate composition analysis}

Table 3: Proximate composition of the product

\begin{tabular}{ll}
\hline Component & Percentage \\
\hline Moisture & $89.53 \pm 0.11$ \\
Total Solids & $10.47 \pm 0.11$ \\
Carbohydrate & $8.27 \pm 0.14$ \\
Protein & $1.80 \pm 0.07$ \\
Crude fat & $0.08 \pm 0.03$ \\
Crude fiber & $0.91 \pm 0.13$ \\
Ash & $0.55 \pm 0.12$ \\
\hline
\end{tabular}

Table 3 shows the proximate composition of the final product. Because of being a beverage, it has a higher moisture content. It was recorded as $89.53 \mathrm{~g}$ per 100 $\mathrm{g}$ of the beverage. The total solids of the beverage were recorded as $10.47 \mathrm{~g}$ per $100 \mathrm{~g}$ of the beverage. This amount was low because of the high moisture content of the beverage. Moreover total carbohydrate, protein, crude fat, crude fiber and ash content of the product were $8.27 \mathrm{~g}, 1.80 \mathrm{~g}, 0.08 \mathrm{~g}, 0.91 \mathrm{~g}$ and 0.55 $\mathrm{g}$ per $100 \mathrm{~g}$ of the beverage respectively.

\section{Physico-chemical analysis of the beverage}

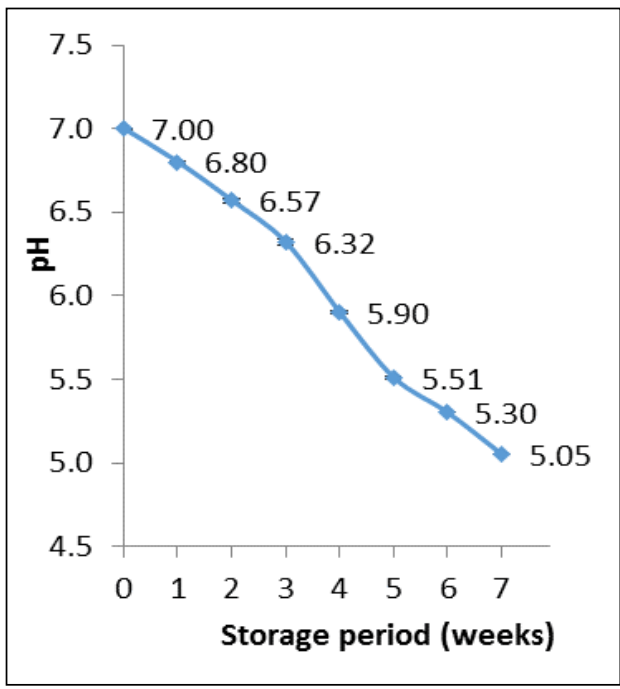

Figure 1: $\mathrm{pH}$ value changes of the beverage during storage period

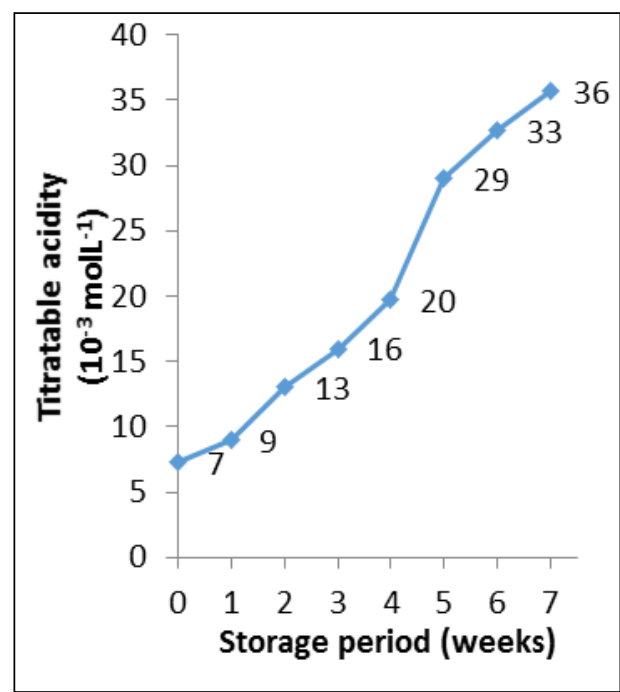

Figure2: Changes of titratable acidity of beverage during storage period 
Changes in lactic acid concentration produced by probiotic bacteria leads to the changes in titratable acidity of the beverage. It was significantly $(p \leq 0.05)$ increased during storage period of 7 weeks (Fig.2).

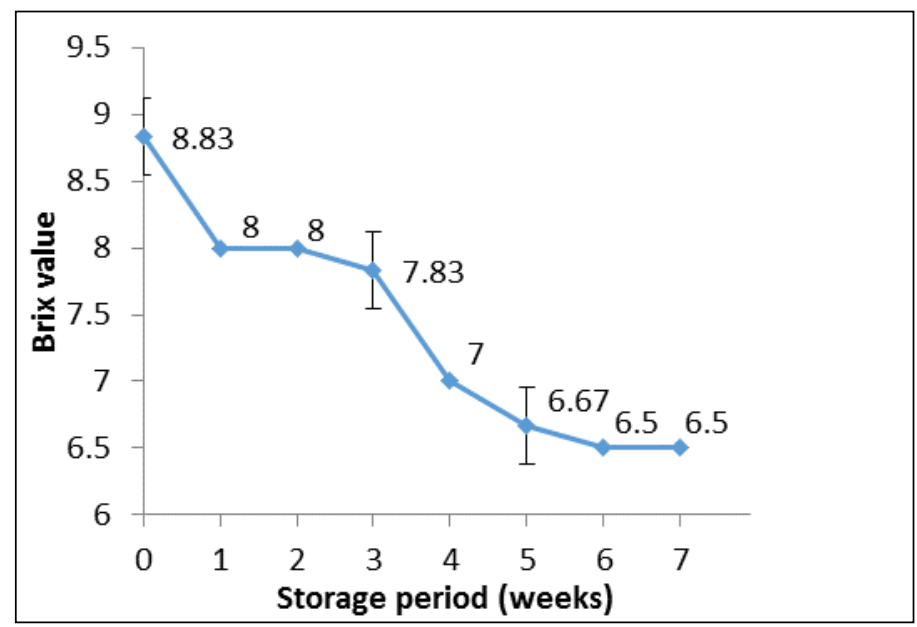

Figure 3: Brix value changes of the beverage during storage

Brix value was significantly reduced with a high reduction rate in $1^{\text {st }}$ and $4^{\text {th }}$ week. After $6^{\text {th }}$ week brix value became a constant (Fig.3).

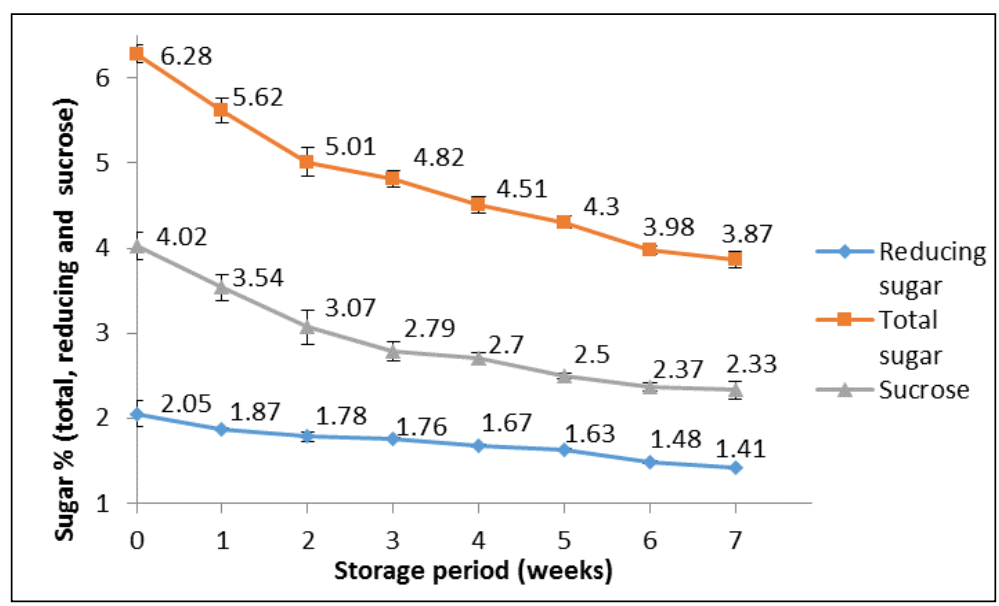

Figure 4: Changes of percentage of total sugars, reducing sugars and sucrose of the beverage during storage period 
Percentage of total sugars (reducing and non-reducing sugars), reducing sugars and sucrose as non-reducing sugar showed high reduction rates. Although there was a significant $(p \leq 0.05)$ reduction in percentage of all sugars, the reduction rate was lowered after $2^{\text {nd }}$ week (Fig.4).

There was no significant $(p>0.05)$ reduction in the crude fiber content of the beverage from initial to $3^{\text {rd }}$ week. At the initial stage, the mean value of crude fiber was recorded as $0.91 \%$ (from the wet basis of the beverage). At the $1^{\text {st }}, 2^{\text {nd }}$ and $3^{\text {rd }}$ week, amount of crude fibers was recorded as $0.91 \%, 0.908 \%$ and $0.905 \%$ respectively.

\section{Microbiological analysis of the beverage}

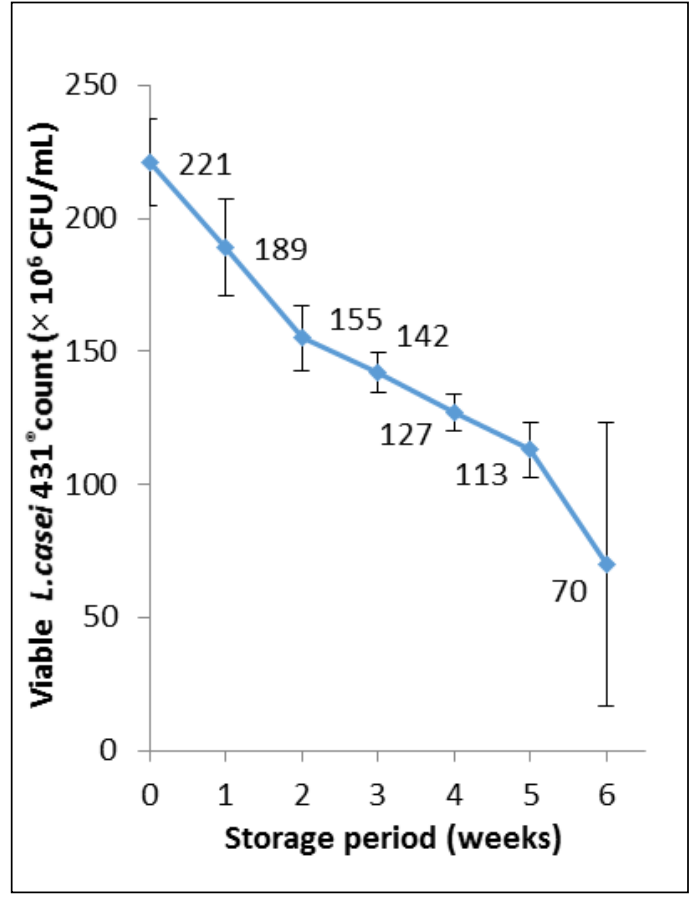

Figure 5: Changes of viability of L.casei431 ${ }^{\circ}$ in the beverage during storage period

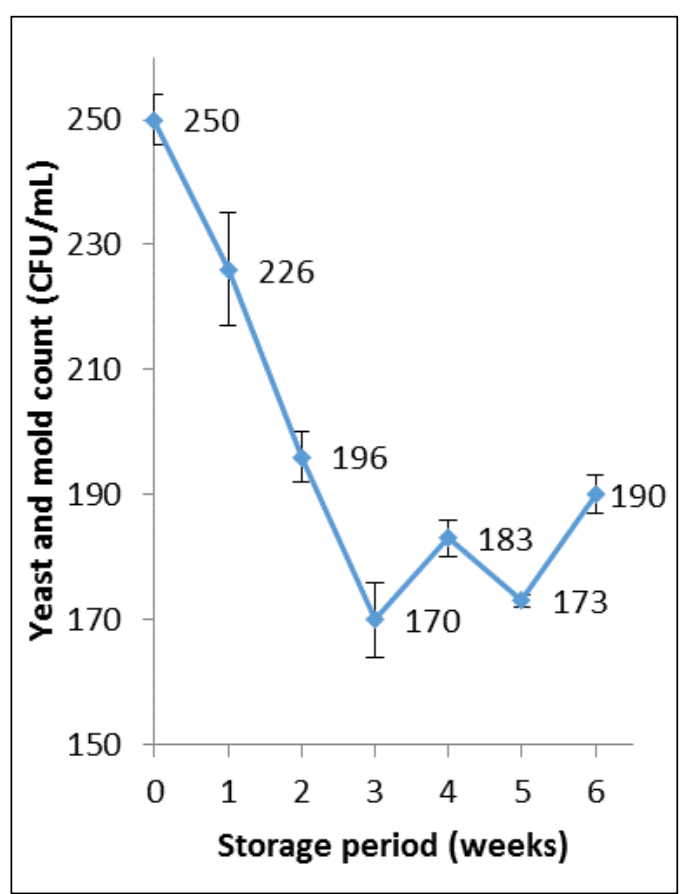

Figure 6: The count of yeast and mold in the beverage during storage period

After fermentation there was $2.21 \times 10^{8} \mathrm{CFU} \mathrm{mL}{ }^{-1}$ of L.casei431 $1^{\circ}$ presented in the beverage (Fig.5). The reduction of viable cells of the beverage at refrigeration ( $5 \pm 1$ ${ }^{\circ} \mathrm{C}$ ) was significant $(p<0.05)$ but the reduction rate was very low in the middle of the storage while the rate was high at the initial and end of the storage (Fig. 5). Finally, 
at the $6^{\text {th }}$ week viable count was recorded as $7.0 \times 10^{7} \mathrm{CFU} \mathrm{mL} \mathrm{mL}^{-1}$. The viability of L.casei431 in this beverage was in an appreciable level under refrigerated condition $\left(5 \pm 1^{\circ} \mathrm{C}\right)$ for 5 weeks but subsequently, the count was exceedingly reduced. According to this result, the finger millet beverage can be considered as a functional beverage up to 5 weeks under refrigerated condition $\left(5 \pm 1^{\circ} \mathrm{C}\right)$.

The count of yeast and mold did not show a gradual increment or decrement throughout the storage period. Until the $3^{\text {rd }}$ week, the count was decreased but after that, there was no any order in count change. Initially the count was $250 \mathrm{CFU} / \mathrm{mL}$ (Fig.6) comparatively a higher value for a beverage.

\section{Shelf life evaluation}

Titratable acidity was increased and $\mathrm{pH}$ was reduced at the end of the storage period of 7 weeks. But it was remained in tolerable acidity and $\mathrm{pH}$ level to the viable L.casei431 $1^{\circ}$ bacteria. There were no changes in sensory attributes until $5^{\text {th }}$ week. Therefore, this beverage could serve as a ready to drink functional beverage under refrigerated $\left(5^{\circ} \mathrm{C} \pm 1\right)$ storage up to 5 weeks.

\section{Discussion}

With regard to the objectives of this study, Lactobacillus casei431 $1^{\circ}$, was found to be growing well on cooked finger millet. Fermentation period of $4 \mathrm{~h}$ at $37^{\circ} \mathrm{C}, \mathrm{L}$. casei $431^{\circ}$ showed a rapid significant growth and it reached nearly $2.0 \times 10^{8} \mathrm{CFU} / \mathrm{mL}$. The viability of the probiotic was significantly reduced during the storage period of 6 weeks but until that viability was appreciable. Viable count at $6^{\text {th }}$ week still stood at nearly $7.0 \times 10^{7} \mathrm{CFU} / \mathrm{mL}$ (Table 4).

Table 4: Changes of viability of L.casei $431^{\circ}$ of the beverage during refrigerated storage

\begin{tabular}{c|c}
\hline Week & $\begin{array}{l}\text { Viable L.casei431 }^{\circ} \\
\left(\times 10^{6} \mathrm{CFU} / \mathrm{mL}\right)\end{array}$ \\
\hline 0 & 221 \\
1 & 189 \\
2 & 1555 \\
3 & 142 \\
4 & 127 \\
5 & 113 \\
6 & 70 \\
\hline
\end{tabular}


For the maximum health benefits, the minimum number of probiotic organism in a food product should be $10^{6} \mathrm{CFU} / \mathrm{mL}$ and to be considered as a functional product the count should be $10^{8} \mathrm{CFU} / \mathrm{mL}$ (Shah, 2001). According to Table 4, at the 0 to $5^{\text {th }}$ week, this beverage enumerated the functional level.

There are several reasons for the reduction of viability of probiotics e.g. lack of essential nutrients (minerals, peptides) for L.casei431 ${ }^{\circ}$, antibacterial substances present in the finger millet, level of oxygen in products, oxygen permeation of the package, fermentation time, and storage temperature (Shah, 2001). Viability also depends on lactic acid concentration. Titratable acidity increases, and the accumulation of lactic acid, leads to $\mathrm{pH}$ reduction. After tolerable acidity and $\mathrm{pH}$ level, lactic acid acts as an inhibitory substance for probiotics. In this study, during the storage period of 5 weeks, $\mathrm{pH}$ was significantly reduced. Although it was a significant reduction, reduction was 7 to 5.05 . At the initial to $7^{\text {th }}$ week, $\mathrm{pH}$ was in tolerable level for probiotics (7-4.5)(Shah, 2007). Consequently titratable acidity showed a significant increment from 0 to $4^{\text {th }}$ week as $0.9 \%$ to $2.0 \%$ but that was in tolerable level for the probiotics (0.3-1.9\%) (Shah, 2007). Therefore, it can be

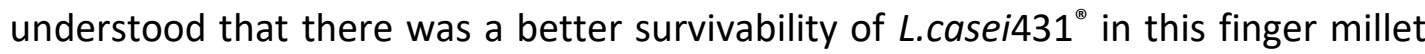
based beverage.

Addition of probiotics changes the organoleptic properties of the beverage by fermentation. Fermentation is a metabolic process of deriving energy from organic compounds without involvement of any exogenous oxidizing agent (Bourdichon, 2012). L.casei $431^{\circ}$ is a homo fermentative bacteria and by fermentation of carbohydrates and prebiotics it only produces lactic acid. The time or extent of fermentation and the temperature affects sensory attributes. In this study, solution was incubated at $37{ }^{\circ} \mathrm{C}$ which was the optimal temperature for L.casei431 ${ }^{\circ}$ (Shah, 2001). Consequently $4 \mathrm{~h}$ fermentation was enough to maintain an overall sensory quality and functional level of the beverage which was proven by the results obtained from sensory evaluations.

USDA has proclaimed that $100 \mathrm{CFU} / \mathrm{mL}$ as the maximum yeast and mold level for ready to serve beverages. But in this beverage, more than that amount was recorded. Literature reveals that there are native yeasts and mold present in the raw finger millets (Mousa, et al., 2015). Although finger millet was boiled, spores of yeasts and molds remained in the beverage. Further yeast and mold can survive in a wide range of temperature and $\mathrm{pH}$ values. This yeast and mold might be helpful for the fermentation process. But undesirable yeast and mold can be contaminated 
during the preparation of beverage, especially at the filling step. Even though the product was pasteurized, hot filling was not practiced because probiotic culture should not be added at high temperatures. If bottles were filled under sterile environment, this problem could have been overcome.

Reduction of total sugar content is the main reason for the reduction of the brix value because of fermentation by L.casei $431^{\circ}$. This was further proved by the results of sugar levels including total sugars, reducing sugars and sucrose as non-reducing sugars, during the storage period. All three sugar levels were significantly reduced when beverage was at the $7^{\text {th }}$ week.This supports and adds to the findings of Nighswonger, Brashears and Gilliland (1996) that fermentation of the beverage has been limited by keeping the beverage in the refrigerator $\left(5 \pm 1{ }^{\circ} \mathrm{C}\right)$.

\section{Conclusion}

Based on the obtained results of this study, it can be concluded there was a better survivability of probiotic Lactobacillus casei $431^{\circ}$ in finger millet based beverage. The count of probiotic organism was within the level of standards $\left(10^{8} \mathrm{CFU} / \mathrm{mL}\right)$ until the end of 5 weeks. Finally, this research has revealed that sensory acceptable finger millet based fermented probiotic beverage can be developed using L.casei $431^{\circ}$ by inoculating $0.031 \mathrm{~g} \mathrm{~L}^{-1}$ inoculum of frozen Lactobacillus casei $431^{\circ}$ and could serve as a ready to drink functional beverage in refrigerated $\left(5 \pm 1^{\circ} \mathrm{C}\right)$ storage up to 5 weeks.

\section{Acknowledgement}

We greatly acknowledge the financial support provided by the Faculty Research Grant, The Open University of Sri Lanka.

\section{References}

Alwis, A.D.P.A., Perera, O.D.A.N., \& Weerahewa, H.L.D. (2016). Development of novel carrot-based symbiotic beverage using lactobacillus casiei 431. Journal of Agricultural Sciences, Sabaragamuwa University, Vol 11, (3), 178-185. DOI: http://doi.org/10.4038/jas.v11i3.8171

A.O.A.C. (2000). Official Methods of Analysis: Sugars (Reducing) in Honey. $17^{\text {th }} \mathrm{Ed}$. Arlington, Virginia: Association of Official Analytical Chemists.

Berner, L. A., \& Donnel. O. (1998). Functional food and health claim legislation: applications to dairy foods. International Dairy Journal, 8(5), 355-362. 
Bourdichon, F. (2012). Food fermentations : Microorganisms with technologicalbeneficial use. International Journal of Food microbiology, 154(3), 87-97.

Collins, C. H., Lyne, P. M., \& Grange, J. M. (2004). Collins and Lyne's microbiological methods. (8th edition).London: Butterworth-Heinemann.

Fuller, R. (1989).Probiotics in man and animals. Journal of Applied Bacteriology, 66, 365-378.

Gamage, S M., Mihirani, M. K. S., Perera, O.D.A.N. \& Weerahewa, H.L.D. (2016). Development of synbiotic beverage from beet root juice using beneficial probiotic Lactobacillus Casei 431. Ruhuna Journal of Science, Vol 07, Issue 02, 70-75.

Gerhardt, P., Murray, R. G. E., Wood, W. A., \& Krieg, N. R. (1994). Methods for general and molecular bacteriology. Washington, DC: ASM Press.

Mousa, W. K., Schwan, A., Davidson, J., Strange, P., Liu, H., Zhou, T., Auzanneau, F.,\&Raizada, M.N. (2015). An endophytic fungus isolated from finger millet (Eleusine coracana) produces anti-fungal natural products. Journal of Frontiers Microbiology, 6, 1157.

Nelson, G., \& George, S. (1995). Comparison of media for selection and enumeration of mouse fecal flora populations, Journal of microbiological methods, 22, 293-300. Retrieved from http://www.sciencedirect.com/science/article/pii/0167701295000045 Nighswonger, B.D., Brashears, M.M.,\& Gilliland, S.E. (1996). Viability of Lactobacillus acidophilus and Lactobacillus casei in fermented milk products during refrigerated storage. Journal of Dairy Science, 79(2), 212-219

Shah, N. P. (2001). Functional foods from probiotics and prebiotics. Food technology, 55(11), 46-53. Retrieved from http://hdl.handle.net/10722/144340 Shah, N. P. (2007). Functional cultures and health benefits. International Dairy journal, 17, 1262-1277. Retrieved from https://www.researchgate.net/publication/222280659-Functional -culturesand-health-benefts

Sharma, C.S. (2006). Chemical and microbiological analysis of milk and milk products. $2^{\text {nd }}$ ed. India: International book distributing Co Publication.

Sripriya, G., Chandrasekharan, K., Murthy, V. S., \& Chandra, T. S.(1996). ESR spectroscopic studies on free radical quenching action of finger millet (Eleusine coracana).Food Chemistry, 57(4),537-540. Retrieved from www.science direct.com/science/article/pii/S0308814696001872 